\title{
Corporate Water Footprint Accounting and Impact Assessment: The Case of the Water Footprint of a Sugar-Containing Carbonated Beverage
}

\author{
A. Ertug Ercin • Maite Martinez Aldaya • \\ Arjen Y. Hoekstra
}

Received: 11 April 2010 / Accepted: 5 October 2010 /

Published online: 23 October 2010

(C) The Author(s) 2010. This article is published with open access at Springerlink.com

\begin{abstract}
All water use in the world is ultimately linked to final consumption by consumers. It is therefore interesting to know the specific water requirements of various consumer goods, particularly the water-intensive ones. This information is relevant not only for consumers, but also for food processors, retailers, and traders. The objective of this paper is to carry out a pilot study on water footprint accounting and impact assessment for a hypothetical sugar-containing carbonated beverage in a 0.51 PET-bottle produced in a hypothetical factory that takes its sugar alternatively from sugar beet, sugar cane and high fructose maize syrup and from different countries. The composition of the beverage and the characteristics of the factory are hypothetical but realistic. The data assumed have been inspired by a real case. This paper does not only look at the water footprint of the ingredients of the beverage, but also at the water footprint of the bottle, other packaging materials and construction materials, paper and energy used in the factory. Although most companies focus on their own operational performance, this paper shows that it is important to consider freshwater usage along the supply chain. The water footprint of the beverage studied has a water footprint of 150 to 3001 of water per 0.51 bottle, of which $99.7-99.8 \%$ refers to the supply chain. The study also shows that agricultural ingredients that constitute only a small fraction in weight of the final product have the biggest share at the total water footprint of a product.
\end{abstract}

Keywords Water footprint • Corporate water strategy • Impact assessment • Sugar $\cdot$ Soft drink

A. E. Ercin $(\varangle) \cdot$ M. M. Aldaya · A. Y. Hoekstra

Twente Water Centre, University of Twente, P.O. Box 217, 7500 AE Enschede,

The Netherlands

e-mail: a.e.ercin@ctw.utwente.nl

M. M. Aldaya

e-mail:m.m.aldaya@ctw.utwente.nl

A. Y. Hoekstra

e-mail: a.y.hoekstra@utwente.nl 


\section{Introduction}

Freshwater in sufficient quantities and adequate quality is a prerequisite for human societies and natural ecosystems (Costanza and Daly 1992). Today, around $70 \%$ of the total freshwater withdrawal by humans is for irrigated agricultural use (Gleick 1993; Bruinsma 2003; Shiklomanov and Rodda 2003; UNESCO 2006). Agriculture as a whole is responsible for about $86 \%$ of the worldwide freshwater use (Hoekstra and Chapagain 2007). Agriculture has to compete with other water users like municipalities and industries (Rosegrant and Ringler 1998; UNESCO 2006). Freshwater is a basic ingredient for many companies' operations, and effluents may pollute the local hydrological ecosystems. Many companies have addressed these issues and formulated proactive management strategies (Gerbens-Leenes et al. 2003). A company may face four serious risks related to failure to manage the freshwater issue: damage to the corporate image, the threat of increased regulatory control, financial risks caused by pollution and insufficient freshwater availability for business operations (Rondinelli and Berry 2000; WWF 2007).

The water footprint is an indicator of water use that looks at both direct and indirect water use of a consumer or producer. The water footprint of an individual, community or business is defined as the total volume of freshwater that is used to produce the goods and services consumed by the individual or community or produced by the business (Hoekstra and Chapagain 2008). Water use is measured in terms of water volumes consumed (evaporated or incorporated into the product) and polluted per unit of time. The water footprint is a geographically explicit indicator, not only showing volumes of water use and pollution, but also the locations. Compared to other water accounting tools, water footprint provides the most extended and complete water accounting method, since it includes both direct and indirect water use and considers both water consumption and pollution. It has already been applied for various purposes, such as the calculation of the water footprint of a large number of products from all over the world (Chapagain and Hoekstra 2004), but so far there have been few applications for business accounting.

The objective of this paper is to carry out a pilot study on water footprint accounting and impact assessment for a hypothetical sugar-containing carbonated beverage in a 0.51 PET-bottle produced in a hypothetical factory that takes its sugar alternatively from sugar beet, sugar cane and HFMS (high fructose maize syrup) sourced from different countries. The aim is primarily to learn from the practical use of existing water footprint accounting and impact assessment methods and to refine these methods and develop practical guidelines. The whole assessment has been inspired by a real case. From a scientific point of view, this paper aims to assess the necessary scope of analysis and, in particular, to explore the degree of detail required in such a study. Finally, an impact assessment of the water footprints is carried out, identifying the hotspots or high-risk areas.

\section{Method}

This study estimates the water footprint of a hypothetical 0.5 1 PET-bottle sugarcontaining carbonated beverage. It looks into more detail at the water footprint of the sugar input, by considering three different sources (sugar beet, sugar cane and 
HFMS) and various countries of origin. The water footprint of different ingredients and other inputs is calculated distinguishing the green, blue and grey water components. The green water footprint refers to the global green water resources (rainwater) consumed to produce the goods and services. The blue water footprint refers to the global blue water resources (surface water and ground water) consumed to produce the goods and services. 'Consumption' refers here to 'evaporation' or 'incorporation into the product'. It does not include water that is withdrawn but returns to the system from where it was withdrawn. The grey water footprint is the volume of polluted water that associates with the production of goods and services. The calculation methods applied in this study follow Hoekstra et al. (2009).

The total water footprint of a business contains various components as shown in Fig. 1. The 'business' considered in this paper refers to the part of the factory that produces our 0.5 1 PET bottle sugar-containing carbonated beverage. The factory produces also other products, but this falls outside the scope of this paper. The water footprint of our product includes both an operational water footprint and a supply-chain water footprint. The operational (or direct) water footprint is the volume of freshwater consumed or polluted in the operations of the business itself. The supply-chain (or indirect) water footprint is the volume of freshwater consumed or polluted to produce all the goods and services that form the input of production of the business. Both operational and supply-chain water footprint consist of two parts: the water footprint that can be directly related to inputs applied in or for the production of our product and an overhead water footprint. In both cases, we distinguish between a green, blue and grey water footprint.

Figure 2 shows the production system of our product. It shows the four main ingredients of the beverage (water, sugar, $\mathrm{CO}_{2}$ and syrup for flavoring) and the other main inputs of production (bottle, cap, label and glue, packing materials).

Water footprint of a business

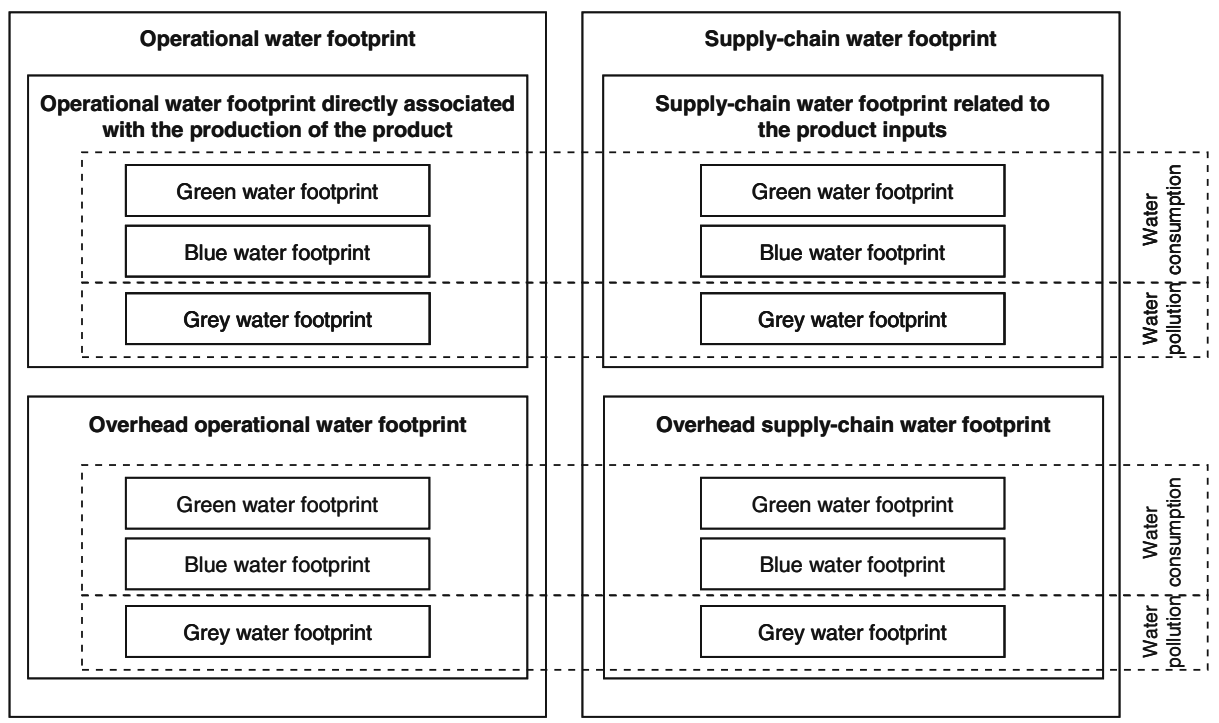

Fig. 1 Composition of the water footprint of a business 


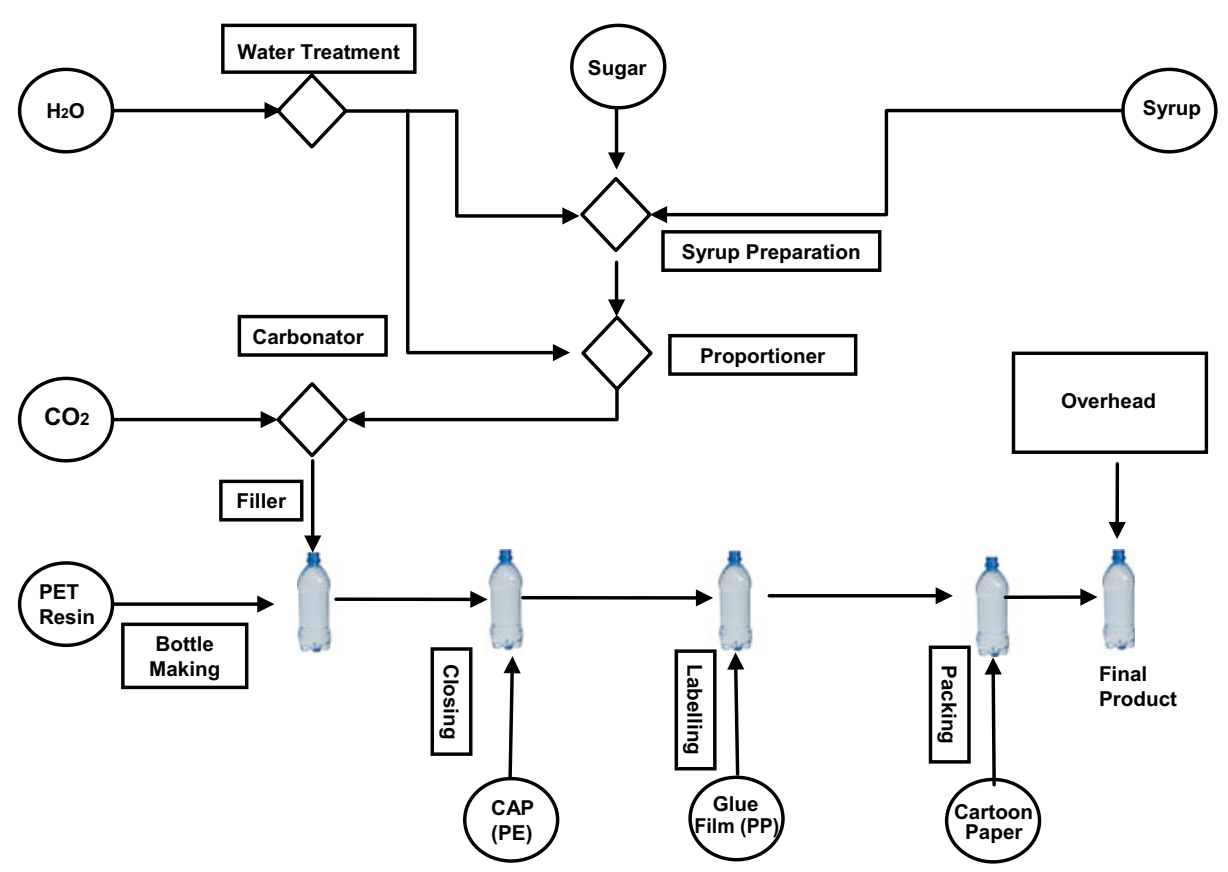

Fig. 2 Production system of the 0.51 PET-bottle sugar-containing carbonated beverage

The production system shown in Fig. 2 does not show the overhead of production. The overhead of production refers to all inputs used that cannot be solely attributed to the production of the specific product considered. The overhead water footprint refers to freshwater use that in first instance cannot be fully associated with the production of the specific product considered, but refers to freshwater use that associates with supporting activities and materials used in the business, which produces not just this specific product but other products as well. The overhead water footprint of a business has to be distributed over the various business products, which is done based on the relative value per product. The overhead water footprint includes, for example, the freshwater use in the toilets and kitchen of a factory and the freshwater use behind the concrete and steel used in the factory and machineries.

\section{Data Sources and Assumptions}

For the assessment, we have formulated a hypothetical sugar-containing carbonated beverage in a 0.51 PET-bottle and a hypothetical factory that takes its sugar alternatively from sugar beet, sugar cane and HFMS (high fructose maize syrup) sourced from different countries. The factory itself is assumed to be in the Netherlands, but many of the inputs come from other countries. The composition of the beverage and the characteristics of the factory are hypothetical but realistic. The set of data assumed has been inspired by a real case. 
3.1 Operational Water Footprint

\subsubsection{Operational Water Footprint Directly Associated with the Production of the Product}

The following components are defined as operational water footprint:

- Water incorporated into the product as an ingredient.

- Water consumed (i.e. not returned to the water system from where it was withdrawn) during the production process (during bottling process, washing, cleaning, filling, labeling and packing).

- Water polluted as a result of the production process.

The first two components form the blue operational water footprint; the third component forms the operational grey water footprint. There is no use of green water (rainwater) in the operations, so there is no operational green water footprint.

The water used as ingredient is 0.51 per bottle. The production of our beverage includes the following process steps: bottle making (from PET resins to PET-bottle forms), bottle cleaning (by air), syrup preparation, mixing, filling, labeling and packing. During all these processes, there is no water consumption.

All wastewater produced during the production steps of the beverage is treated at a municipal wastewater treatment plant. The concentrations of chemicals in the effluent of the wastewater treatment plant are equal and in some instances even lower than the natural concentrations in the receiving water body. With this assumption, the grey component of the operational water footprint is effectively zero.

\subsubsection{Overhead Operational Water Footprint}

The overhead operational water footprint is the water consumed or polluted as a result of:

- Water consumption by employees (drinking water).

- Water consumption or pollution as a result of water use in toilets and kitchen.

- Water consumed or polluted due to washing of the working clothes of the employees.

- Water consumed or polluted due to cleaning activities in the factory.

- Water consumption in gardening.

The factory considered in this study produces a number of different beverage products; our beverage is just one of them. Therefore, only a fraction of the total overhead water footprint is attributed to our beverage product, based on the ratio of the annual value related to the production of this specific product to the annual value of all products produced in the factory. The annual production value of our beverage product is $10 \%$ of the total production value of all beverage products produced by the factory.

In this study we assume that drinking water is negligible and that there is no gardening. It is further assumed that all water used during the other activities specified above returns to the public sewerage system and is treated in a municipal wastewater treatment plant such that the effluent causes no grey water footprint. As a result, the overhead operational water footprint is estimated as zero. 


\subsection{Supply-Chain Water Footprint}

\subsubsection{Supply-Chain Water Footprint Related to the Product Inputs}

The supply-chain water footprint related to product inputs consists of the following components:

- Water footprint of product ingredients other than water (sugar, CO2, phosphoric acid, caffeine from coffee beans, vanilla extract, lemon oil and orange oil).

- Water footprint of other inputs used in production (bottle, cap, labeling materials, packing materials).

Table 1 specifies, per ingredient, the precise amount contained in a 0.51 bottle. It also shows which raw material each ingredient underlies and what the country of origin of the raw material is. In the case of sugar, the study considers three alternative sources: sugar beet, sugar cane and maize (which is used to make high fructose maize syrup). Table 1 also specifies the amounts of the other inputs used, again per 0.51 bottle. The figures for the amounts used are based on realistic values, similar to the ones on the commercial market. During bottle production, $25 \%$ of the material consists of recycled material. This ratio is taken into account in the calculations by using a

Table 1 Ingredients and other items used for the sugar-containing carbonated beverage (per 0.51 bottle)

\begin{tabular}{|c|c|c|c|}
\hline Item & $\begin{array}{l}\text { Amount } \\
\text { (grams) }\end{array}$ & Raw material & Origin of raw material \\
\hline Sugar & $50^{\mathrm{a}}$ & Sugar beet & $\begin{array}{l}\text { Iran, Russia, USA, Italy, Spain, } \\
\text { France, The Netherlands }\end{array}$ \\
\hline Sugar & $50^{\mathrm{a}}$ & Sugar cane & $\begin{array}{l}\text { Cuba, Pakistan, Brazil, India, } \\
\text { Peru, USA }\end{array}$ \\
\hline Sugar & $50^{\mathrm{a}}$ & HFSM & India, USA, France, China \\
\hline $\mathrm{CO}_{2}$ & 4 & Ammonia by product & The Netherlands \\
\hline Caffeine & 0.05 & Coffee beans & Colombia \\
\hline Phosphoric acid & 0.2 & $\begin{array}{l}\text { Phosphate rock—by } \\
\text { chemical process }\end{array}$ & USA \\
\hline Vanilla extract & 0.01 & Vanilla beans & Madagascar \\
\hline Lemon oil & 0.007 & Lemon & World market \\
\hline Orange oil & 0.004 & Orange & World market \\
\hline Bottle-PET & 19.5 & Oil & World market \\
\hline Closure-HDPE & 3 & Oil & World market \\
\hline Label—PP & 0.3 & Oil & World market \\
\hline Label glue & 0.18 & Glue & World market \\
\hline Tray glue & 0.015 & Glue & World market \\
\hline Tray cartoon-paperboard & 2.8 & Wood & World market \\
\hline Tray shrink film-PE & 1.6 & Oil & World market \\
\hline Pallet stretch wrap-PE & 0.24 & Oil & World market \\
\hline Pallet label $(2 \times)$-coated paper & 0.003 & Wood & World market \\
\hline Pallet-painted wood & 0.09 & Wood & World market \\
\hline
\end{tabular}

${ }^{a}$ Breedveld et al. (1998) 
fraction of 0.75 to calculate the amount of new material used. A similar approach has been used for pallets, which have a lifespan of 10 years (fraction 0.1 applied to the total used).

For the beverage ingredients, data on the water footprints of the raw materials, process water requirements, and product and value fractions, are presented in Table 2. The water footprints of the various forms of sugar from different countries have been taken mainly from Gerbens-Leenes and Hoekstra (2009). For four selected countries (France, Italy, Spain and the Netherlands), the water footprint of sugar beet is specifically calculated as part of the scope of this study. The water footprints of other ingredients are taken from Chapagain and Hoekstra (2004). For the other inputs used in the production of a 0.51 bottle of our beverage, water footprints of raw materials and process water requirements are presented in Table 3.

\subsubsection{Overhead Supply-Chain Water Footprint}

The overhead supply-chain water footprint originates from all goods and services used in the factory that are not directly used in or for the production process of one particular product produced in the factory. The factory produces other products than our 0.51 PET bottle of sugar-containing carbonated beverage as well, so the overhead water footprint needs to be allocated only partly to our product.

Goods that could be considered for the calculation of the overhead supply-chain water footprint are for example: construction materials and machineries used in the factory, office equipments and materials, cleaning equipments and materials, kitchen equipments and materials, working clothes used by employees, transportation, and energy for heating and power. This list can be extended further. For the scope of this study, it was decided to include some selected materials for the calculation of overhead water footprint in order to understand the influence of such elements on the total water footprint of the final product. The materials selected for assessment are the following:

- Construction materials (concrete and steel)

- Paper

- Energy in the factory (natural gas and electricity)

- Transportation (vehicles and fuel)

The amounts of materials used in our factory are specified in Table 4. For paper and energy use in the factory and transportation fuels, annual amounts are given. For construction materials and vehicles, total amounts are given with a specification of the lifespan of the totals. The lifespan can be used to calculate annual figures from the totals. For the vehicles, it is assumed that average lifespan of a track is 10 years. Table 5 gives the water footprints of the raw materials relating to the overhead goods and the process water requirements.

The value of the 0.51 PET bottles of our beverage is $10 \%$ of the total value of products produced in the factory. Therefore, $10 \%$ of the total overhead water footprint of the factory will be allocated to our product. The annual production is 30 million bottles per year, so the overhead water footprint per bottle is found by dividing the overhead water footprint insofar allocated to our product by 30 million. 


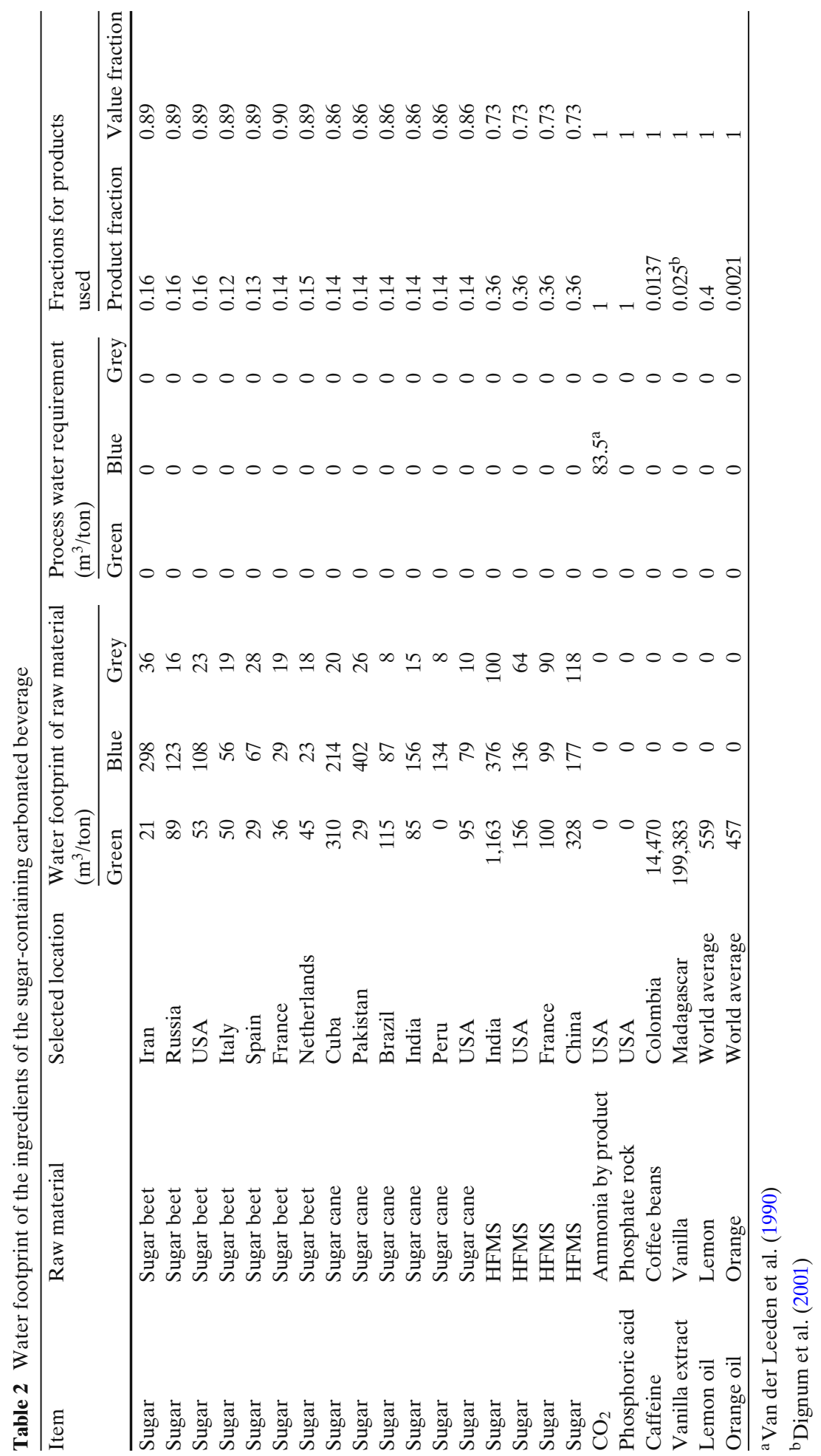




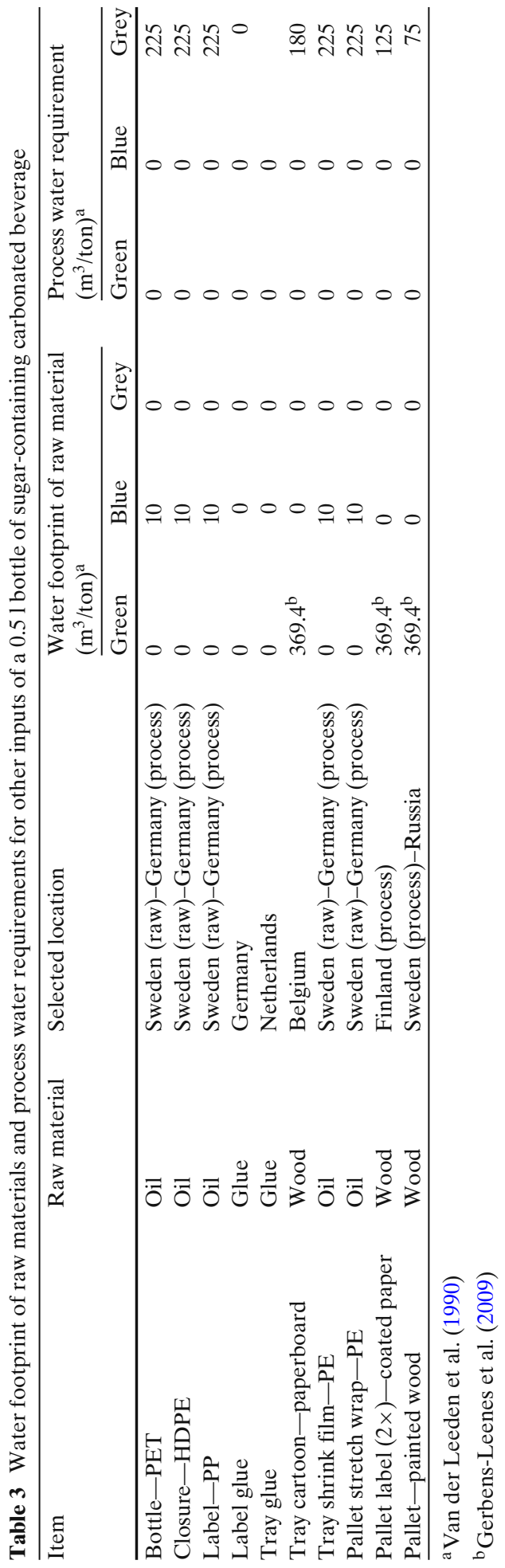


Table 4 List of selected goods and services for assessing the overhead supply-chain water footprint

\begin{tabular}{|c|c|c|c|c|c|c|c|}
\hline Item & $\begin{array}{l}\text { Total amount } \\
\text { used }\end{array}$ & Unit & $\begin{array}{l}\text { Raw } \\
\text { material }\end{array}$ & $\begin{array}{l}\text { Amount of } \\
\text { raw material }\end{array}$ & $\begin{array}{l}\text { Unit of raw } \\
\text { material }\end{array}$ & $\begin{array}{l}\text { Lifespan of } \\
\text { material }\end{array}$ & $\begin{array}{l}\text { Yearly } \\
\text { amount }\end{array}$ \\
\hline Concrete & 30,000 & Ton & Cement & 30,000 & Ton & 40 & 750 \\
\hline Steel & 5,000 & Ton & Steel & 5,000 & Ton & 20 & 250 \\
\hline Paper & 1 & Ton/year & Wood & 1 & Ton/year & - & 1 \\
\hline Natural gas & 65,000 & GJ/year & Gas & 65,000 & GJ/year & & 65,000 \\
\hline Electricity & 85,000 & GJ/year & Several & 85,000 & GJ/year & & 85,000 \\
\hline Vehicles & 40 & Numbers & Steel & 11.6 & Tons/vehicle & 10 & 46.4 \\
\hline Fuel & 150,000 & Liters/year & Diesel & 150,000 & Liters/year & - & 150,000 \\
\hline
\end{tabular}

\section{Results}

\subsection{Water Footprint of a 0.5 1 PET-Bottle Sugar-Containing Carbonated Beverage}

The total water footprint of our beverage amounts to 169 to 3091 (Table 6). In calculating the total water footprint of the product, the amounts of all ingredients and other inputs are kept constant; only the type and origin of the sugar is changed in order to understand the effect of sugar type and production location on the total water footprint of the beverage. The effect of the type and origin of sugar used is shown in Fig. 3.

The total water footprint of the beverage is the highest (309 1) when the sugar originates from cane sugar from Cuba, and the lowest (169 1) when the sugar comes from beet sugar from the Netherlands. If we compare the beet sugars, our product has the highest water footprint when beet sugar is from Iran (241 1) followed by Russia (206 1), USA (194 1), Italy (189 1), Spain (185 l), France (170 l) and the Netherlands (169 1). For sugar cane, our beverage has the highest water footprint when we take the cane from Cuba (309 1), followed by Pakistan (283 1), India (221 1), Brazil (207 1), USA (199 1) and Peru (186 1). When we use HFMS as a sweetener, the order is: India (309 1), China (206 l), USA (179 l) and France (172 1).

Table 5 Supply-chain water footprint of the selected overhead goods and services

\begin{tabular}{|c|c|c|c|c|c|c|c|c|}
\hline \multirow[t]{2}{*}{ Item } & \multirow[t]{2}{*}{$\begin{array}{l}\text { Raw } \\
\text { material }\end{array}$} & \multirow{2}{*}{$\begin{array}{l}\text { Selected location for } \\
\text { the calculation of the } \\
\text { water footprint }\end{array}$} & \multicolumn{3}{|c|}{$\begin{array}{l}\text { Water footprint of } \\
\text { raw material }\left(\mathrm{m}^{3} / \text { ton }\right)\end{array}$} & \multicolumn{3}{|c|}{$\begin{array}{l}\text { Process water } \\
\text { requirement }\left(\mathrm{m}^{3} / \text { ton }\right)^{\mathrm{a}}\end{array}$} \\
\hline & & & Green $^{b}$ & Blue $^{\mathrm{a}}$ & Grey & Green & Blue & Grey \\
\hline Concrete & Cement & Belgium (process) & 0 & 0 & 0 & 0 & 0 & 1.9 \\
\hline Steel & Steel & $\begin{array}{l}\text { Sweden (process)- } \\
\text { USA (raw material) }\end{array}$ & 0 & 4.2 & 0 & 0 & 0 & 61 \\
\hline Paper & Wood & Finland (process) & 369.4 & 0 & 0 & 0 & 0 & 125 \\
\hline Natural gas & Gas & World average & 0 & 0 & 0 & 0 & 0 & 0.11 \\
\hline Electricity & Several & World average & 0 & 0 & 0 & 0 & 0 & 0.47 \\
\hline Vehicles & Steel & $\begin{array}{l}\text { Sweden (process)- } \\
\text { USA (raw material) }\end{array}$ & 0 & 4.2 & 0 & 0 & 0 & 61 \\
\hline Fuel & Diesel & World average & 0 & 0 & 0 & 0 & 0 & 1.06 \\
\hline
\end{tabular}

${ }^{a}$ Van der Leeden et al. (1990)

${ }^{\mathrm{b}}$ Gerbens-Leenes et al. (2009) 
Table 6 The total water footprint of a 0.5 1 PET-bottle sugar-containing carbonated beverage

\begin{tabular}{lllll}
\hline Item & \multicolumn{2}{l}{ Water footprint (liters) } & & Total \\
\cline { 2 - 5 } & Green & Blue & Grey & 0.5 \\
\hline Operational water footprint & 0 & 0.5 & 0 & $168-308.9$ \\
Supply-chain water footprint $^{\mathrm{a}}$ & $134.5-252.4$ & $7.4-124$ & $9.2-19.7$ & $168.5-309.4$ \\
Total $^{\mathrm{a}}$ & $134.5-252.4$ & $7.9-124.5$ & $9.2-19.7$ & 16.9 \\
\hline
\end{tabular}

${ }^{\text {a }}$ The range reflects the fact that we have considered different types and origin of the sugar input

Almost the entire water footprint of the product is stemming from the supplychain water footprint (99.7-99.8\%). This shows the importance of a detailed supply chain assessment. Common practice in business water accounting, however, is to focus on operational water consumption. The results of this study imply that compared to the traditional water use indicator (water withdrawal for the own operations), the water footprint provides much more information. In this particular case, the operational water footprint cannot be lowered because it is precisely equal to the amount needed as an ingredient to the beverage. The traditional indicator of water withdrawal would show a larger number, because withdrawals include return flows, while the water footprint excludes those, because return flows can be reused, so they do not impact on the available water resources like consumptive water use does. In our case, there is no consumptive water use and wastewater is treated properly before returned to the system.

Figure 4 shows the color composition of the total water footprint of the product for two different countries. Pakistan has the one with the highest ratio for blue water footprint. The Netherlands has the highest ratio for green water footprint.

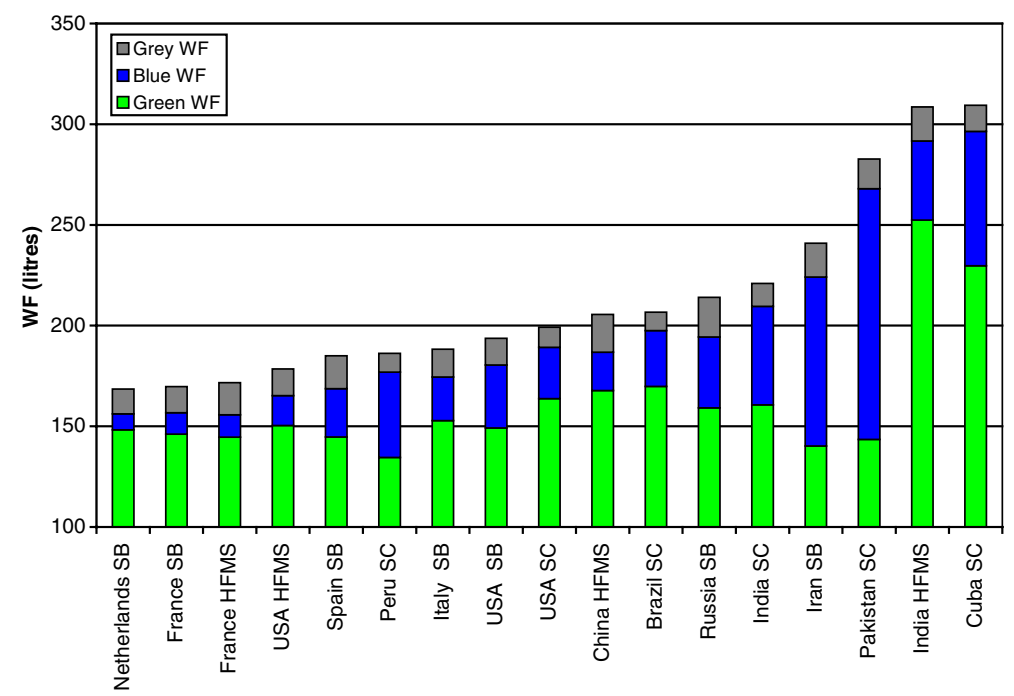

Fig. 3 The total water footprint of 0.5 1 PET-bottle sugar-containing carbonated beverage according to the type and origin of the sugar ( $S B$ sugar beet, $S C$ sugar cane, HFMS high fructose maize syrup) 
Fig. 4 The water footprint colour composition of a 0.51 PET-bottle sugar-containing carbonated beverage for Pakistan (sugar cane) and the Netherlands (sugar beet)

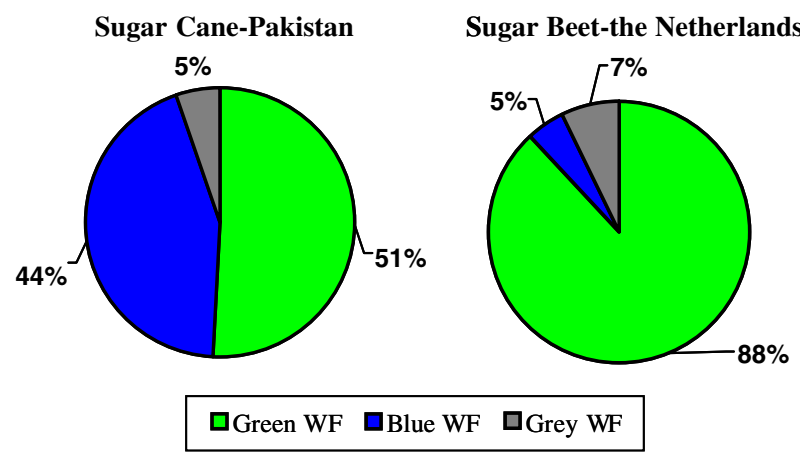

\subsubsection{Supply-Chain Water Footprint}

The supply-chain water footprint of our beverage is calculated as a summation of the water footprints of all inputs (both ingredients and other inputs) and the water footprint of overhead activities. Table 7 presents the various components of the supply-chain water footprint of our beverage product.

Table 7 The supply-chain water footprint of a 0.51 PET-bottle sugar-containing carbonated beverage

\begin{tabular}{|c|c|c|c|c|}
\hline \multirow[t]{2}{*}{ Item } & \multicolumn{4}{|c|}{ Supply-chain water footprint (liters) } \\
\hline & Green & Blue & Grey & Total \\
\hline Sugar & See Table 8 & See Table 8 & See Table 8 & See Table 8 \\
\hline $\mathrm{CO}_{2}$ & 0 & 0.3 & 0 & 0.33 \\
\hline Phosphoric acid or citric acid (e338) & 0 & 0 & 0 & 0 \\
\hline Caffeine & 52.8 & 0 & 0 & 52.8 \\
\hline Vanilla extract & 79.8 & 0 & 0 & 79.8 \\
\hline Lemon oil & 0.01 & 0 & 0 & 0.01 \\
\hline Orange oil & 0.9 & 0 & 0 & 0.9 \\
\hline Bottle-PET & 0 & 0.2 & 4.4 & 4.5825 \\
\hline Closure-HDPE & 0 & 0.03 & 0.68 & 0.7 \\
\hline Label-PP & 0 & 0.003 & 0.068 & 0.07 \\
\hline Label glue (not included) & 0 & 0 & 0 & 0 \\
\hline Tray glue (not included) & 0 & 0 & 0 & 0 \\
\hline Tray cartoon-paperboard & 1 & 0 & 0.5 & 1.5 \\
\hline Tray shrink film-PE & 0 & 0.02 & 0.36 & 0.38 \\
\hline Pallet stretch wrap-PE & 0 & 0.003 & 0.054 & 0.057 \\
\hline Pallet label $(2 \times) —$ coated paper & 0.001 & 0 & 0.0004 & 0.0015 \\
\hline Pallet—painted wood & 0.033 & 0 & 0.007 & 0.04 \\
\hline Concrete & 0 & 0 & 0.005 & 0.005 \\
\hline Steel & 0 & 0.004 & 0.05 & 0.054 \\
\hline Paper & 0.0012 & 0 & 0.0004 & 0.0016 \\
\hline Natural gas & 0 & 0 & 0.024 & 0.024 \\
\hline Electricity & 0 & 0 & 0.13 & 0.13 \\
\hline Vehicles & 0 & 0.001 & 0.009 & 0.01 \\
\hline Fuel & 0 & 0 & 0.5 & 0.5 \\
\hline Total & $134.5-252.4$ & $7.4-124$ & $9.2-19.7$ & 168-308.9 \\
\hline
\end{tabular}


Sugar is one of the main water consuming ingredients in our beverage. One of the aims of this paper is to understand the effect of sugar type and origin on the total water footprint of the beverage. For this purpose, three different commonly used sugar types are selected: sugar beet, sugar cane and HFMS. For each type, some production countries are selected for the calculation, which have high, low and average water footprints. Table 8 presents the water footprint of the sugar input in our beverage product as a function of sugar type and origin.

When we choose to use sugar beet as sugar source of our hypothetical beverage, the water footprint of the sugar input can vary from 261 per 0.51 bottle (when the sugar beets are grown in the Netherlands) to 98.51 (Iran). If our source is sugar cane, the water footprint of the sugar input can vary from 43.91 per bottle (Peru) to 1671 (Cuba). If we would use HFMS as a sweetener, not so usual in the world but common in the US, the water footprint of the sugar input will range from 29.31 per bottle (when the maize comes from France) to $166 \mathrm{l}$ (India). It is important to identify and analyze the colors of the water footprint of the product in order to assess the impacts of the water footprints. The highest blue water footprint related to the sugar input alone is 1241 with sugar cane from Pakistan and the lowest is 71 with sugar beet from the Netherlands. The grey water footprint of the sugar input is the lowest when the sugar intake is cane sugar from Brazil (2.4 1), and highest with HFMS from China (12 1). This analysis shows that sugar type and production location affect the total water footprint of the product and the ratios green/blue/grey significantly.

Table 8 The water footprint of the sugar input for a 0.51 PET-bottle sugar-containing carbonated beverage

\begin{tabular}{|c|c|c|c|c|c|}
\hline \multirow[t]{2}{*}{ Item } & \multicolumn{4}{|c|}{ Water footprint (liters) } & \multirow[t]{2}{*}{ Remarks $^{\mathrm{a}}$} \\
\hline & Green & Blue & Grey & Total & \\
\hline \multicolumn{6}{|l|}{ Beet sugar } \\
\hline $\operatorname{Iran}^{\mathrm{a}}$ & 5.7 & 82.8 & 10.0 & 98.5 & Highest WF, highest blue WF \\
\hline Russia $^{\mathrm{a}}$ & 24.6 & 34.1 & 4.5 & 63.3 & High WF, big producer \\
\hline $\mathrm{USA}^{\mathrm{a}}$ & 14.7 & 30.1 & 6.4 & 51.2 & Second biggest producer in the world \\
\hline Italy $^{\mathrm{a}}$ & 18.6 & 20.8 & 7.1 & 46.5 & Close to global average WF \\
\hline Spain $^{\mathrm{a}}$ & 10.0 & 23.1 & 9.7 & 42.8 & Close to global average WF \\
\hline France $^{\mathrm{a}}$ & 11.7 & 9.5 & 6.2 & 27.4 & Biggest producer in the world \\
\hline Netherlands ${ }^{\mathrm{b}}$ & 13.6 & 7.0 & 5.4 & 26.0 & Very low WF \\
\hline \multicolumn{6}{|l|}{ Cane sugar ${ }^{\mathrm{a}}$} \\
\hline Cuba & 95.2 & 65.7 & 6.2 & 167.0 & Highest WF \\
\hline Pakistan & 9.0 & 123.5 & 8.0 & 140.4 & High WF, highest blue WF \\
\hline Brazil & 35.3 & 26.6 & 2.4 & 64.3 & Biggest producer in the world \\
\hline India & 26.2 & 47.9 & 4.6 & 78.6 & Second biggest producer in the world \\
\hline Peru & 0.0 & 41.3 & 2.6 & 43.9 & Lowest WF \\
\hline USA & 29.3 & 24.4 & 3.2 & 56.8 & Close to world average \\
\hline \multicolumn{6}{|l|}{ HFMS $55^{\mathrm{a}}$} \\
\hline India & 117.9 & 38.2 & 10.2 & 166.2 & Highest WF \\
\hline USA & 15.9 & 13.8 & 6.5 & 36.1 & $\begin{array}{l}\text { Biggest producer in the world and highest } \\
\text { rate of maize usage for sugar input }\end{array}$ \\
\hline France & 10.1 & 10.0 & 9.2 & 29.3 & Low WF \\
\hline China & 33.3 & 17.9 & 12.0 & 63.2 & Close to global average WF \\
\hline
\end{tabular}

${ }^{\mathrm{a}}$ Gerbens-Leenes and Hoekstra (2009)

${ }^{\mathrm{b}}$ Own calculations 
It shows that including the spatial dimension in water footprint assessment is indeed important.

In our hypothetical beverage, the amounts of vanilla extract $(0.01 \mathrm{~g})$ and caffeine from coffee beans $(0.05 \mathrm{~g})$ inputs are very small in the total amount of the beverage. Although their physical content in the beverage is small $(0.09 \%$ for caffeine and $0.02 \%$ for vanilla), their contribution to the total water footprint of the product is very high (maximum $33 \%$ for caffeine and $50 \%$ for vanilla). This study reveals that, without prior knowledge about the relevance of different inputs, a detailed and comprehensive supply-chain analysis is essential for the calculation of the water footprint of a product. Even small ingredients can significantly affect the total water footprint of a product.

\subsubsection{Operational Water Footprint}

The operational water footprint of a 0.5 1 PET-bottle sugar-containing carbonated beverage has a number of components as shown in Table 9. Both green and grey water footprints are zero. The blue water footprint is 0.51 of water for one bottle. The total operational water footprint is thus no more than the water used as ingredient of the beverage. The 'water footprint' of the operations is lower than the 'water withdrawal' of the factory, because all water withdrawn by our hypothetical factory is returned (except for the water used as ingredient for the beverage) and purified before disposal.

\subsection{Impact Assessment of a 0.5 1 PET-Bottle Sugar-Containing \\ Carbonated Beverage}

According to its definition, the water footprint concept is a geographically explicit indicator, not only showing volumes of water use and pollution, but also showing the various locations where the water is used (Hoekstra and Chapagain 2008). This

Table 9 The operational water footprint of a 0.51 PET-bottle sugar-containing carbonated beverage

\begin{tabular}{lllll}
\hline Item & \multicolumn{4}{l}{ Operational water footprint (liters) } \\
\cline { 2 - 5 } & Green & Blue & Grey & Total \\
\hline $\begin{array}{l}\text { Inputs } \\
\text { Direct water used for a }\end{array}$ & 0 & 0.5 & 0 & 0.5 \\
$\quad 0.5$ l PET (as ingredient) & & & & \\
Net water used in & 0 & 0 & 0 & 0 \\
$\quad$ production steps & & & & \\
$\quad$ Bottle making & 0 & 0 & 0 & 0 \\
$\quad$ Bottle cleaning (by air) & 0 & 0 & 0 & 0 \\
Ingredients mixing & 0 & 0 & 0 & 0 \\
$\quad$ Packing & 0 & 0 & 0 & 0 \\
Overhead & & & & 0 \\
$\quad$ Domestic water & 0 & 0 & 0 & 0 \\
$\quad$ consumption & & & & \\
Total operational water & 0 & 0.5 & 0 & 0.5 \\
footprint & & & & \\
\hline
\end{tabular}


means, water footprint analysis of a business/product shows the impact of business activities on nature and society by answering two fundamental questions: where (location) and when (time). It is also useful to show the blue, green and grey components of the water footprint of a business/product, because the impact of the water footprint will depend on whether it concerns the evaporation of abstracted ground or surface water, the evaporation of rainwater used for production or pollution of freshwater.

Assessment of the impacts of a water footprint starts with quantifying, localizing and describing the color of the water footprint. Next step is to identify the vulnerability of the local water systems where the footprint is located, the actual competition over the water in these local systems and the negative externalities associated with the use of the water. This kind of an assessment may lead to a corporate water strategy to reduce and offset the impacts of the water footprint (Hoekstra 2008). The goals of a business with respect to reducing and offsetting the impacts of its water footprint can be prompted by the goal to reduce the business risks related to its freshwater appropriation. Alternatively, they can result from governmental regulations with respect to water use and pollution.

It is important to understand and evaluate the environmental impacts of all crops if we are to achieve sustainable production systems. Understanding the impact of sugar beet, sugar cane and HFMS are particularly important as there are different countries where they can be grown, and also because there is a growing interest in their potential as a source for biofuel (Gerbens-Leenes and Hoekstra 2009).

For the impact assessment of sugar usage, we compare the water footprint of sugar beet, cane and HFMS as quantified in the previous section with the water scarcity in the different regions where the water footprint is located following the method developed by Van Oel et al. (2008). For this purpose, a water scarcity indicator by Smakhtin et al. (2004a, b) was used. This indicator deals with the withdrawalto availability ratio per river basin taking into account the environmental water requirements, which are subtracted from runoff.

Sugar Beet With a population of more than 65 million people, Iran is actually one of the most water-scarce countries of the world. It is estimated that the average annual supply of renewable freshwater per person will fall from 1,750 (2005) to $1,300 \mathrm{~m}^{3}$ (2020). According to the 'Falkenmark thresholds', a country will experience periodic water stress when freshwater availability is below $1,700 \mathrm{~m}^{3}$ per person per year (Falkenmark and Rockström 2004). More than 94\% of the total annual water consumption in Iran is used for agriculture, so agriculture plays a significant role in water stress in the country. In addition, the productivity of water (yield per unit of water) is very low. The water footprint of Iranian sugar beet is one of the highest in the world (Gerbens-Leenes and Hoekstra 2009). The Iranian sugar beet usage in our product leads to 991 of water consumption per bottle, $84 \%$ of which are from blue water sources. Amongst all countries, sugar beet cultivation in Iran requires the most irrigation (highest blue water footprint). This leads to serious water problems in sugar beet cultivation regions, especially where the production rate is high. Onethird of the country's sugar factories are in the three provinces of Razavi Khorasan, Northern Khorasan and Southern Khorasan Iran that experience mostly arid climatic 
conditions and currently experiencing extreme water shortages. This problem has become more visible, especially in these specific parts of the country, due to recent droughts (Larijani 2005).

Another country with a high water footprint of sugar intake is Russia with a sugarrelated water footprint of 631 per bottle. Similar to Iran, the blue water footprint of sugar beet in Russia is high, i.e. $53 \%$ of the total water footprint. The most important problem due to sugar beet cultivation in Russia is in the area north of the Black Sea. Pollution in the rivers Dnieper and Don, which flow to the Black Sea, is causing serious environmental damage to the Black Sea ecosystem. In 1992, The Russian Federation's Committee on Fishing reported several cases of water bodies were completely contaminated by agricultural runoff. Besides pollution by excessive use of fertilizers, irrigation has also resulted in water scarcity in some areas (GerbensLeenes and Hoekstra 2009).

Andalucia is a clear hotspot since it is a water scarce region with a high water footprint in relation to sugar beet production. Sugar beet irrigation in this region has contributed to lower water levels in the Guadalquivir River, limiting water reaching important wetlands during summer (WWF 2004).

The water quality issue is a major concern since the overuse of fertilizers on beet crops is typical of farming in general (WWF 2004). Environmental impacts generally arise because the nutrients in the fertilizers are not entirely taken up by the crop but move into the environment. The runoff of nitrate and phosphate into lakes and streams can contribute to accelerated eutrophication and the proliferation of toxic microalgae. In the Seine-Normandy basin, irrigation has little quantitative impact on the resource, but does, however, have an indirect impact on quality because it favors intensive farming techniques and spring crops, which leave the soil bare for long periods of the year and increase the chemical load in the rivers by leaching and draining (UNESCO 2003). This has a harmful effect on both the environment and other water uses. Improving water quality is still a major concern of the basin, where non-point source pollution from farming and urban areas is still a major problem as nitrate, pesticide and heavy metal concentrations continue to increase (ibid.).

Sugar Cane Sugarcane is the most important plant in Cuba and it was the most important foreign exchange earner of the tropical island for decades. The water footprint of sugar intake for our beverage is the highest when sugar is sugar cane sourced from Cuba, with 1671 per bottle. Sugar cane production in Cuba has also the highest water footprint in the world compared to other sugar types and production locations. Cuba has been facing several environmental problems for the last decades in relation to sugar cane production. Cuba has high-quality resources of karst water, but the quality of this water is highly susceptible to pollution. Pollution resulting from sugar cane factories is one of the main reasons that the quality of karst aquifers has deteriorated (León and Parise 2008). In addition, the untreated wastewater discharge from sugar factories in Cuba has led to oxygen deficiency in rivers and the dominance of aquatic macrophytes, which results in thick mats of weeds. This situation partially blocks the water delivery capacity of canals, which has negative effects on fishing and tourism (WWF 2004). Due to sugar cane cultivation, deforestation in Cuba has become a major environmental problem (Monzote 2008). Cuba's forest area has also been drastically decreased as a result of demand for lumber; the sugar cane industry alone annually consumes 1 million cubic meters of firewood (Cepero 2000). 
Another country with a high water footprint of sugar cane is Pakistan. If we choose Pakistani sugar cane for our product, the water footprint of sugar intake will be 1401 per bottle. The sugar cane in Pakistan heavily depends on irrigation; the blue water footprint constitutes $88 \%$ of the total water footprint. Water abstractions for irrigation cause water shortage in the production regions and serious environmental problems. The Indus River is the major water resource of Pakistan. The freshwater reaching the Indus Delta has significantly decreased (90\%) as a result of over-usage of water sources in the Indus basin. Sugar cane is one of the main water consuming agricultural products in the basin. The decrease in freshwater flow to the Indus Delta has negative impacts on the biodiversity of the Delta (decrease of mangrove forestlands, and danger of extinction of the blind river dolphin). Additionally, excessive water use in sugar cane cultivation areas also leads to salinity problems in Pakistan (WWF 2004). Moreover, untreated wastewater discharge from sugar mills causes depletion of available oxygen in water sources which results in endangering fish and other aquatic life (Akbar and Khwaja 2006).

Being the largest sugar cane producer in the world, Brazil has faced several negative impacts of sugar cane production. However, most of the sugar cane produced is used as raw material for ethanol production. Extensive sugar cane production and demand in Brazil has led to deforestation of rain forests. Moreover, sugarcane fields in the state of San Paulo are reported to cause air pollution due to preharvest burning (WWF 2004). Water pollution due to sugar cane industry and sugar cane agricultural practice (fertilizers and pesticides) is another major environmental problem in Brazil (Gunkel et al. 2006).

Like other countries, India is also facing environmental problems due to sugar cane cultivation. In the Indian state of Maharashtra, sugar cane irrigation uses $60 \%$ of the total irrigation supply, which causes substantial groundwater withdrawals (WWF 2004). India's largest river, the Ganges, experiences severe water stress. Sugar cane is one of the major crops cultivated in the area and increases water scarcity (GerbensLeenes and Hoekstra 2009). Another problem resulting from sugar cane cultivation and sugar processing activity in India is the pollution of surface and groundwater resources (Solomon 2005).

Other Ingredients and Inputs The results presented earlier in this chapter show that vanilla, which is part of the natural flavor of our beverage, contributes largely to the overall water footprint (from $27 \%$ to $50 \%$ ). The source of the vanilla is Madagascar, which is the main vanilla producing country in the world. Cultivation of vanilla is one of the most labor-intensive agricultural crops and it takes up to 3 years before the crop can be harvested. Harvested flowers need a process called curing in order to take its aroma. This process needs heating of the vanilla beans in hot water $\left(65^{\circ} \mathrm{C}\right)$ for 3 min, which causes most environmental problems in the production countries. Thermal pollution occurs as a result of hot water discharged into freshwater systems, causing sudden increases in the temperature of the ambient water systems above ecologically acceptable limits. In addition to water contamination by means of temperature changes, the necessity of obtaining wood, the main energy source of heating, causes deforestation of rainforests (TED 2003).

Another small ingredient of our hypothetical beverage is caffeine. Although the amount of caffeine used in the product is small, the water footprint is very high (53 1 per bottle). The caffeine is sourced from coffee beans produced in Colombia, which 
is one of the biggest coffee producers in the world. Two major problems exist in Colombia due to coffee cultivation: loss of bird species and soil erosion. Additionally, pollution of surface and ground water resources resulting from usage of fertilizers is a major environmental problem due to coffee cultivation (TED 2001).

The oil based materials used for the bottle of our beverage (PET-bottle, cap, stretch films and labels) have particularly a grey water footprint. In PE production, large amounts of water are used for cooling. Cooling water is considered as grey water as it increases the temperature of the receiving freshwater bodies more than what is acceptable from an ecological point of view. Water quality criteria for aquatic ecosystems indicate that water temperature may not increase by more than a few degrees Celsius compared to natural conditions (CEC 1988). Additional freshwater sources are required to dilute hot water stemming from cooling water (to decrease the temperature of discharged cooling water in order to meet standards with respect to maximum increase of water temperature).

\section{Conclusion}

The total water footprint of our beverage is calculated as minimum 1691 (using sugar beet from the Netherlands) and maximum 3091 (using sugar cane form Cuba). The operational water footprint of the product is 0.51 , which forms $0.2-0.3 \%$ of the total water footprint. The supply-chain water footprint constitutes $99.7-99.8 \%$ of the total water footprint of the product.

The operational water footprint of the 0.51 PET-bottle sugar-containing carbonated beverage consists of two components: the operational water footprint the 'overhead water footprint'. The first is equal to the water incorporated into the product, which is 0.51 . There is no other operational water footprint than this, because there is no other water consumption or pollution in the factory related to the production of the product.. There is water use in the factory for general purposes such as flushing toilets, cleaning working clothes, and washing and cooking in the kitchen, but all water used is collected and treated in a public wastewater treatment plant before it is returned into the environment. Thus, the net abstraction from the local water system for those activities is zero.

The supply-chain water footprint of the product also consists of two components: related to product inputs (ingredients and other inputs) and overhead. Most of the supply-chain water footprint of the product is coming from its ingredients (95-97\%). A smaller fraction of the supply-chain water footprint comes from the other inputs (2-4\%), mainly from the PET-bottle. The overhead water footprint constitutes a minor fraction of the supply-chain water footprint $(0.2-0.3 \%)$.

The main impacts of the hypothetical product are stemming from the grey and blue water footprints of the product. Ingredients like sugar, vanilla, caffeine (coffee) cause contamination of natural freshwater sources (grey water footprint) because of the use of fertilizers and pesticides. The biggest impact of the water footprint of the beverage is related to the sugar ingredient. Many sugar producing countries are water-rich countries where the water footprint does not relate to water stress. There are, though, several localized hotspots, such as the sugar beet production in the Andalucia region in the South of Spain, sugar cane production in Pakistan (Indus River) and India (Ganges River), and sugar beet from Iran. With regard to 
water quality, pollution by nitrates is an issue in several regions, such as the case of Northern France, Russia (Black Sea), India, Pakistan, Cuba, Brazil, Iran and China. A rational $\mathrm{N}$ fertilization is important to reduce the environmental impact of fertilization and to increase profitability in crop production. Better management practices to reduce the environmental impacts in the sugar industry do not necessarily imply reduced productivity and profits; indeed, measures to address environmental impacts can provide economic benefits for farmers or mills through cost savings from more efficient resource use. In addition, mostly sugar cane production relates to deforestation like in Cuba and Brazil. Other negative effects of sugar production are impacts on biodiversity (decrease of mangrove forestlands, and danger of extinction of the blind river dolphin in the Indus Delta).

The results of this study show the importance of a detailed supply-chain assessment in water footprint accounting. Common practice in business water accounting is mostly restricted to the analysis of operational water use. This study shows that compared to the supply-chain water footprint, the operational side is almost negligible. The results of this study imply that compared to other water accounting tools, the concept of the water footprint provides a more comprehensive tool for water accounting.

The study shows that the water footprint of a beverage product is very sensitive to the production locations of the agricultural inputs. Even though the amount of sugar is kept constant, the water footprint of our product significantly changes according to the type of sugar input and production location of the sugar. Additionally, the type of water footprint (green, blue and grey) changes according to location, which are mainly driven by the difference in climatic conditions and agricultural practice in the production locations. These results reveal the importance of the spatial dimension of water footprint accounting.

The study reveals that detailed and comprehensive supply-chain analysis is essential for the calculation of the water footprint of a product. It shows that even small ingredients can significantly affect the total water footprint of a product. On the other hand, the study also shows that many of the components studied hardly contribute to the overall water footprint.

The general findings of this study with respect to the ratio of operational to supplychain water footprint and the relative importance of ingredients, other inputs and overhead can be extended to other beverages similar to our hypothetical beverage. The major part of the water footprint of most beverages will be stemming from the supply chain. The operational water footprint of the beverages similar to ours will be negligible compared to the water footprint of the ingredients. This shows the importance of focusing cooperate water policy towards to supply chain rather than operational water use.

This is the first study quantifying the overhead water footprint of a product. Strictly spoken, this component is part of the overall water footprint of a product, but it was unclear how relevant it was. This study reveals that the overhead component is not important for this kind of studies and is negligible in practice.

By definition, the water footprint is a geographically explicit indicator, not only showing volumes of water use and pollution, but also showing the various locations where the water is used and the periods of the year in which the water is used (Hoekstra and Chapagain 2008). The question in practical applications is, however, whether it is feasible to trace the precise locations and timing of water use in the 
supply chain of a product. In the current water footprint study for a 0.51 PET-bottle sugar-containing carbonated beverage we show that it is feasible to trace water use in the supply-chain relatively well, based on a desk study only. Even better and more precise results could be obtained in a more elaborate study including visits to the suppliers and finally to the farmers and mining industries producing the primary ingredients. Knowing the blue, green and grey components of the water footprint of a product and the precise locations and timing of water use is essential for water footprint impact assessment, which in turn is key for formulating mitigating policies. Accurate material flow accounting along the full supply-chain of a product would simplify water footprint accounting.

Open Access This article is distributed under the terms of the Creative Commons Attribution Noncommercial License which permits any noncommercial use, distribution, and reproduction in any medium, provided the original author(s) and source are credited.

\section{References}

Akbar NM, Khwaja MA (2006) Study on effluents from selected sugar mills in Pakistan: potential environmental, health, and economic consequences of an excessive pollution load. Sustainable Development Policy Institute, Islamabad

Breedveld BC, Hammink J, Van Oosten HM (eds) (1998) Nederlandse voedingsmiddelentabel, Voedingscentrum (Nutrition Council). The Hague, The Netherlands

Bruinsma J (ed) (2003) World agriculture: towards 2015/2030: an FAO perspective. Earthscan, London, UK

CEC (1988) European community environmental legislation: 1967-1987, Document Number XI/989/87. Directorate-General for Environment, Consumer Protection and Nuclear Safety, Commission of European Communities, Brussels, Belgium

Cepero E (2000) La Situación Ambiental de Cuba al Finalizar el Siglo XX. Cuba in Transition. In: Papers and proceedings of the eleventh annual meeting of the association for the study of the Cuban economy, vol. 10. University of Miami, Miami, pp 1-17

Chapagain AK, Hoekstra AY (2004) Water footprints of nations. Value of water research report series no. 16. UNESCO-IHE, Delft, The Netherlands

Costanza R, Daly HE (1992) Natural capital and sustainable development. Conserv Biol 6:37-46

Dignum MJW, Kerler J, Verpoorte R (2001) Vanilla production: technological, chemical, and biosynthetic aspects. Food Rev Int 17(2):119-120

Falkenmark M, Rockström J (2004) Balancing water for humans and nature: the new approach in ecohydrology. Earthscan, London

Gerbens-Leenes PW, Moll HC, Schoot Uiterkamp AJM (2003) Design and development of a measuring method for environmental sustainability in food production systems. Ecol Econ 46:231248

Gerbens-Leenes PW, Hoekstra AY, Van der Meer Th (2009) The water footprint of energy from biomass: a quantitative assessment and consequences of an increasing share of bio-energy in energy supply. Ecol Econ 68(4):1052-1060

Gerbens-Leenes PW, Hoekstra AY (2009) The water footprint of sweeteners and bio-ethanol from sugar cane, sugar beet and maize. Value of water research report series no. 38, UNESCO-IHE. Delft, The Netherlands

Gleick PH (ed) (1993) Water in crisis: a guide to the world's fresh water resources. Oxford University Press, Oxford

Gunkel G et al (2006) Sugar cane industry as a source of water pollution-case study on the situation in Ipojuca River, Pernambuco, Brazil. J Water Air Soil Pollut 180(1):261-269

Hoekstra AY, (2008) Water neutral: reducing and offsetting the impacts of water footprints. Value of water research report series no. 28. UNESCO-IHE, Delft, The Netherlands

Hoekstra AY, Chapagain AK (2007) Water footprints of nations: water use by people as a function of their consumption pattern. Water Resour Manage 21(1):35-48 
Hoekstra AY, Chapagain AK (2008) Globalization of water: sharing the planet's freshwater resources. Blackwell, Oxford

Hoekstra AY, Chapagain AK, Aldaya MM, Mekonnen MM (2009) Water footprint manual: state of the art 2009. Water footprint network. Enschede, The Netherlands

Larijani KM (2005) Iran's water crisis: inducers, challenges and counter-measures. In: ERSA 45th congress of the European regional science association. Vrije University, Amsterdam, The Netherlands

León LM, Parise M (2008) Managing environmental problems in Cuban karstic aquifers. Environ Geol 58(2):275-283

Monzote RF (2008) From rainforest to cane field in Cuba: an environmental history since 1492. University of North Carolina Press, Chapel Hill

Rondinelli DA, Berry MA (2000) Environmental citizenship in multinational corporations: social responsibility and sustainable development. Eur Manag J 18(1):70-84

Rosegrant MW, Ringler C (1998) Impact on food security and rural development of transferring water out of agriculture. Water Policy 1(6):567-586

Shiklomanov IA, Rodda JC (2003) World water resources at the beginning of the twenty-first century. Cambridge University Press, Cambridge

Smakhtin V, Revenga C, Döll P (2004a) Taking into account environmental water requirements in global-scale water resources assessments. Comprehensive assessment research report 2. IWMI, Colombo, Sri Lanka

Smakhtin V, Revenga C, Doll P (2004b) A pilot global assessment of environmental water requirements and scarcity. Water Int 29(3):307-317

Solomon SK (2005) Environmental pollution and its management in sugar industry in India: an appraisal. J Sugar Tech 7(1):77-81

TED (2001) Coffee market and Colombia. In: Miura A (ed) TED case studies, vol 11(2). American University, Washington

TED (2003) A taste of vanilla. In: Alwahti A Y (ed) TED case studies, number 686. American University, Washington, USA

UNESCO (2003) Water for people, water for life: 1st United Nations world water development report, part : case studies, chapter 19. UNESCO Publishing, Paris/Berghahn Books, Oxford

UNESCO (2006) Water, a shared responsibility: the United Nations world water development report 2. UNESCO Publishing, Paris/Berghahn Books, Oxford

Van der Leeden F, Troise FL, Todd DK (1990) The water encyclopaedia, 2nd edn. Lewis, USA

Van Oel PR, Mekonnen MM, Hoekstra AY (2008) The external water footprint of the Netherlands: quantification and impact assessment. Value of water research report series no. 33. UNESCO-IHE. Delft, The Netherlands

WWF (2004) Sugar and the environment: encouraging better management practices in sugar production. WWF global freshwater programme. WWF, Zeist, The Netherlands

WWF (2007) A water scarcity risk-a typology. World Wildlife Fund, Godalming 